\title{
Effect of the monocyte locomotion inhibitory factor (MLIF) produced by E. histolityca on cytokines and chemokine receptors in T CD4+ lymphocytes
}

\author{
SARA ROJAS-DOTOR ${ }^{1}$, JULIA PÉREZ-RAMOS², JUAN ANTONIO GIMÉNEZ- \\ SCHERER $^{1}$, FRANCISCO BLANCO-FAVELA ${ }^{1}$ and GUADALUPE RICO-ROSILLO ${ }^{1}$
}

\footnotetext{
${ }^{1}$ Unidad de Investigación Médica en Inmunología, Hospital de Pediatría, Centro Médico Nacional Siglo XXI, IMSS,

${ }^{2}$ Universidad Autónoma Metropolitana División de Ciencias Biológicas y de la Salud, México, D. F.
}

\begin{abstract}
Entamoeba histolytica produces Monocyte Locomotion Inhibitory Factor (MLIF), which may contribute to the delayed inflammation observed in amoebic hepatic abscesses. Leukocytes are affected through the modulation of cytokine expression and/or production. We evaluated the effects of MLIF on the activation and production of intracellular cytokines in human CD4+ T lymphocytes by flow cytometry. Cells were stimulated for $24 \mathrm{~h}$ with PMA, MLIF, or PMA+MLIF. Cellular activation was measured using anti-CD69. Th1/Th2 production was studied by the expression of intracellular cytokines and cytokine/chemokine receptors. MLIF increased CD69 and induced the over-expression of the IL-1 $\beta$, IFN- $\gamma$, IL-2, IL-4, and IL-10 intracellular cytokines; PMA+MLIF inhibited Th1 cytokine (IFN- $\gamma$ ) and increased Th2 cytokines (IL-4 and IL-10). The co-expression of the cytokine and chemokine receptors IFN- $\gamma /$ CCR 5 and IL-1 $\beta / C C R 5$ was inhibited by PMA+MLIF and Th2 co-expression was increased.

MLIF effects varied depending on the conditions. MLIF alone activated the Th1 and Th2 cytokines and cytokine/receptor expression; however, PMA+MLIF increased the expression of Th2 but inhibited it in Th1.

Key terms: Amebic hepatic abscess (AHA); CC chemokine receptors (CCR4, CCR5); monocyte locomotion inhibitory factor (MLIF); Entamoeba histolytica (E. histolytica); 1-phorbol-12 myristate-13 acetate (PMA), interleukin (IL), T helper 1 lymphocyte (Th1); T helper 2 lymphocyte Th2)
\end{abstract}

\section{INTRODUCTION}

Activation of lymphocytes is a complex, yet finely regulated cascade of events that results in the expression of cytokine receptors, the production and secretion of cytokines, and the expression of several cell surface molecules, eventually leading to divergent immune responses. Parasitespecific immune responses are regulated by cytokines and chemokines. They modulate and direct the immune expression but may also contribute to an infection induced by the pathogenesis and parasite persistence (Talvani et al., 2004). Parasitic infections frequently result in highly polarized $\mathrm{CD}^{+}$
T cell responses, characterized by dominant Th1 or Th2 cytokine production profiles. Although it was previously thought that these infections were strictly dependent on signaling by differentiated cytokines, as IFN- $\gamma$, IL-12 and IL-4, recent data indicate that this polarization may be primarily decided by a series of different factors, intrinsic to the pathogen-antigenpresenting-cell interaction that direct $\mathrm{T}$ cell priming and all this is influenced by the local environment (Katzman et al., 2008). The infection caused by $E$. histolytica parasite is associated with an acute inflammatory response (Chadee and Meerovitch, 1984). However, it is not

Correspondence: Sara Rojas-Dotor. Unidad de Investigación Médica en Inmunología, Hospital de Pediatría, CMN-SXXI. Avenida Cuauhtémoc 330, Col. Doctores, C. P. 06720, México D. F., México, Tel/fax +52 55 5627-6943. e-mail: srdotor@yahoo.com.mx 
completely clear how E. histolytica triggers the host inflammatory response and how host-parasite interaction starts, modulates, and eventually turns off these events.

Axenically cultured Enatamoeba histolytica (E. histolytica) produces a pentapeptide (Met-Gln-Cys-Asn-Ser) called Monocyte Locomotion Inhibitory Factor (MLIF) with a molecular weight of 583 Daltons. In vitro, it inhibits the locomotion of human monocytes and does not affect the neutrophil polimorfonucleares and the respiratory burst in either human neutrophils or monocytes, nor does it affect their viability (Rico et al., 1992). In vivo, mononuclear leukocyte arrival is delayed in Rebuck windows of human skin chambers (Kretschmer et al., 1985), while in guinea pigs and gerbils, MLIF inhibits cutaneous dinitrochlorobenzene (DNCB) delayed hypersensitivity (Giménez-Scherer et al., 1997). In addition, MLIF decreases VLA-4 adhesion molecule expression in monocytes and VCAM-1 adhesion molecule expression in vascular epithelium (Giménez-Scherer et al., 2000). The selective actions of MLIF upon a variety of cell types suggested that it disrupts an organism's pro- and antiinflammatory network (Kretschmer et al., 1985, Giménez-Scherer et al., 1987, Kretschmer R et al., 2001). A pentapeptide with the same amino acids but in a different sequence (MLIF scramble, Gln-Cys-MetSer-Asn) showed no anti-inflammatory properties (Giménez-Scherer et al., 2004). Such effect could be attributed to the chemical activity of the peptide. Ongoing studies in quantum chemistry have revealed that a pharmacophore group in the MLIF sequence (Cys-Asn-Ser) could be responsible for most anti-inflammatory properties of the molecule (Soriano-Correa et al., 2006).

The interaction between chemokines and chemokine receptors is an important step in controlling leukocyte migration into inflammation sites. Chemokines also mediate a variety of effects independent of chemotaxis, including the induction and enhancement of Thl and Th2-associated cytokine responses (Campbell et al., 2000). Thl responses preferentially induce CCR5 and CXCR3 while Th2 responses induce
CCR4 and CCR8 (Sebastiani et al., 2001, Loetscher et al., 1998, Andrew et al., 2001). These differential patterns of chemokine receptor expression suggest a mechanism for the selective induction of migration and activation of Thl and Th2 cells during inflammation and, perhaps, normal immune homoeostasis (D Ambrosio et al., 1998, Sallusto et al., 1998). Cellular immunityinflammation-related cytokines (represented by interleukin [IL]-1- $\beta$, IL-2, and interferon gamma $[\mathrm{IFN}]-\gamma$ ) are characteristic of a Thl response, while anti-inflammatory cytokines (typically IL-4 and IL-10) are associated with a Th2 response (Mosmann and Fong 1989). During inflammation, leukocytes are orchestrated and regulated by the mononuclear leukocyte Th1/Th2 derived cytokine network. Thus, it was interesting for us to evaluate the effects of MLIF on lymphocyte activation and Thl/Th2 cytokine production. Additionally, it has been suggested that $E$. histolytica invasion occurs within a territory where the Thl response can be inhibited, this is, in an unbalanced environment where Thl $<$ Th2. In this work, we evaluated the in vitro effect of MLIF on the activation and production of Thl/Th2 intracellular cytokines (IL-1 $\beta$, IL- 2, INF- $\gamma$ IL-4, and IL-10) and the relation with the chemokine receptors CCR4 and CCR5 in human CD4+ T cells.

\section{MATERIALS AND METHODS}

\section{Cell purification}

Thirty $\mathrm{ml}$ of venous heparinized blood were obtained from healthy, nonsmoking adult volunteer donors $(n=30)$ of both sexes. Blood was diluted 1:2 with phosphate buffered saline (PBS; $0.15 \mathrm{M}$ phosphate buffer), then $10 \mathrm{ml}$ of sample was layered over $4 \mathrm{ml}$ of Ficoll-Hypaque (Sigma Chemical Co., St. Louis, MO) gradient $(\delta=1.077)$ and centrifuged at $700 \mathrm{~g}$ for 30 min at $21^{\circ} \mathrm{C}$ (Böyum, 1968). The cellular interface peripheral blood mononuclear cells (PBMC) were removed and washed two times with PBS. CD4+ T cells were purified using the CD4+ T cell isolation kit II, as an indirect magnetic labeling system 
for the isolation of untouched CD4+ T cells from human PBMCs (Miltenyi Biotec, Germany), and LS column and MidiMACS separator. Briefly, 1 x $10^{7}$ PBMC cells were placed in propylene tubes with $80 \mu \mathrm{l}$ PBSalbumin-EDTA and $20 \mu \mathrm{l}$ cocktail of biotin-conjugated antibodies against CD8, CD11b, CD16, CD19, CD36, CD56, CD123, TCR $\gamma / \delta$, and CD235a (Glycophorin A) and incubated for $10 \mathrm{~min}$ at $4^{\circ} \mathrm{C}$. These cells were subsequently magnetically labeled with Anti-Biotin MicroBeads for depletion. The CD4+ lymphocytes obtained were $95 \%$ pure.

\section{Monocyte Locomotion Inhibitory Factor (MLIF)}

MLIF (Met-Gln-Cys-Asn-Ser) 96\% pure was commercially obtained (American Peptide Co., Sunnyvale, CA, USA). All working solutions were tested for endotoxin (LPS $<0.3$ pg) using Limulus assay (Amoebocyte Lysate Endosafe KTA Charles River Endosafe INC, Charleston, $\mathrm{SC}, \mathrm{USA}$ ) and kept at $-70{ }^{\circ} \mathrm{C}$ until use.

\section{Culture cells}

Five $x 10^{5}$ CD4+ T cells were placed in 24well plates in: 1) RPMI-1640 medium alone (supplemented with $10 \%$ fetal calf serum (FCS), 2 mM L-glutamine, $100 \mathrm{U} / \mathrm{ml}$ streptomycin, $5 \mu \mathrm{g} / \mathrm{ml}$ gentamicin, and $1 \mathrm{mM}$ sodium pyruvate, (Gibco Laboratories, Grand Island, NY, USA), or 2 ) in medium supplemented with 1-phorbol12 myristate-13 acetate (PMA) $(50 \mathrm{ng} / \mathrm{ml})$ (Sigma, Chemical Co, St. Louis MO), or 3) in medium with MLIF $(50 \mu \mathrm{g} / \mathrm{ml})$, or 4) PMA+MLIF for $24 \mathrm{~h}$ at $37{ }^{\circ} \mathrm{C}, 5 \% \mathrm{CO}_{2}$ (Freshney et al., 1987). Cell viability was $\geq$ $90 \%$ by Trypan blue dye (Sigma) exclusion. The optimal concentrations of MLIF and PMA were determined by dose-response curves.

Expression of CD-69, chemokine receptors, and intracellular cytokines

The activation of lymphocytes, both in vivo and in vitro, induced the expression of CD69. This molecule was involved in lymphocyte proliferation, expression of different surface molecules and functions as a signal-transmitting receptor in lymphocytes (Cambiaggi et al., 1992, Reddy et al., 2004). The cells were first stained to detect their surface markers using monoclonal antibodies (mAb) labeled with fluorescein isothiocyanate (FITC) or phycoerythrin (PE): anti-CD69, anti-CD3, anti-CD4, anti-human CCR4, and antihuman CCR5, mouse IgG isotype control (PharMingen San Diego, CA, USA), followed by a permeabilization step and staining with the following anti-human mAbs: anti- IL- $1 \beta$, anti-IL-2, anti-IFN- $\gamma$, anti-IL-4, and anti-IL-10 (PharMingen San Diego, CA, USA). The cells were also stained to detect chemokine receptors and cytokine with the following combinations of $\mathrm{mAb}$ : anti-IL-1 $\beta$ PE/anti-CCR5FITC, anti-IL2FITC/anti-CCR5PE, anti-IFN $\gamma$ PE/ anti-CCR5FITC, anti-IL-4PE/antiCCR4FITC and anti-IL-10FITC/antiCCR4PE (PharMingen). Briefly, $5 \times 10^{5}$ CD4+ $\mathrm{T}$ cells from each group were incubated in 24-well plates for $24 \mathrm{~h} ; 10 \mu \mathrm{g} /$ $\mathrm{ml}$ brefeldin $\mathrm{A}$ were added and incubated for the last 6 hours. After incubation, cells were centrifuged for $5 \mathrm{~min}$ at $400 \mathrm{~g}$ and supernatants were aspirated without disturbing pellets. Cells were washed with $\mathrm{PBS} / 0.5 \%$ albumin/2mM EDTA. They were then marked with $\mathrm{mAb}$, and incubated for $20 \mathrm{~min}$ at $4^{\circ} \mathrm{C}$ in the dark, and fixed with $1 \%$ p-formaldehyde (Sigma Chemical Co., St. Louis, MO) according to the manufacturer's instructions (PharMingen). Acquisition of 10,000 events was conducted in flow cytometry FACScalibur (BD Biosciences, Palo Alto, CA). For analysis, Win MDI 2.8 software was used (Miltenyi, et al., 1990).

\section{STATISTICAL ANALYSIS}

All data are presented as mean \pm standard error of the mean (SEM). $n=3$ for figure 1 and $2, n=6$ for the other figures. Statistical comparison among groups was performed using the Mann-Whitney $U$ tests. Differences were considered as statistically significant when $\mathrm{p}<0.05$. 


\section{RESULTS}

Determination of CD69 expression by CD4+ T cells

To determine the activation cell by MLIF, CD4+ lymphocytes were cultured in presence of RPMI, MLIF, PMA, or PMA+MLIF. The results showed that $2 \%$ of CD4+ T lymphocytes expressed CD69 constitutively (control). When the cells were stimulated with MLIF, $38 \%$ of CD4+ T lymphocytes expressed CD69 with a significant difference $(\mathrm{p}<0.002)$. When stimulated with PMA, $46 \%$ expressed CD 69, and with PMA+MLIF the expression marker was present in $28 \%(\mathrm{p}<0.05 \%)$. PMA+MLIF significantly decreased the expression of CD69 (figure 1).

\section{CCR4, CCR5, and CCR4/CCR5 expression}

After testing the ability of MLIF to activate CD4+T cells, we demonstrated the different expressions of CCR4, CCR5, and CCR4/ CCR5 chemokine receptors.
In unstimulated cells (RPMI), 16\% IL$1 \beta$ of CD4+ T cells expressed CCR $4,18 \%$ expressed CCR5 and $12 \%$ expressed CCR4/ CCR5. In stimulated with MLIF cells (MLIF) $19 \%$ of CD4+ T cells expressed CCR 4, 25\% expressed CCR5, and 43\% expressed CCR4/CCR5. In summary, MLIF up-regulated the chemokine receptors, being statistically significant for CCR5 $(\mathrm{p}<0.05)$ and CCR4/CCR5 $(\mathrm{p}<0.05)$, but not for CCR4 (figure 2).

\section{Th1/Th2 intracellular cytokine production}

We wondered if the effect of MLIF on the expression of intracellular cytokine was related to Th1 or Th2 cytokines pattern. Therefore, the production of IL-1 $\beta$, IL-2, IFN- $\gamma$, IL-4, and IL-10 by flow cytometry was first analyzed. Constitutive expression (PBS) of intracellular cytokines was 3\%, $5 \%, 0.7 \%, 4 \%$, and $1 \%$, respectively; MLIF increased the expression of all of them to $24 \%, 31 \%, 10 \%, 28 \%$, and $16 \%$, respectively. Cytokines production after PMA treatment $(69 \%, 52 \%, 22 \%, 46 \%$, and
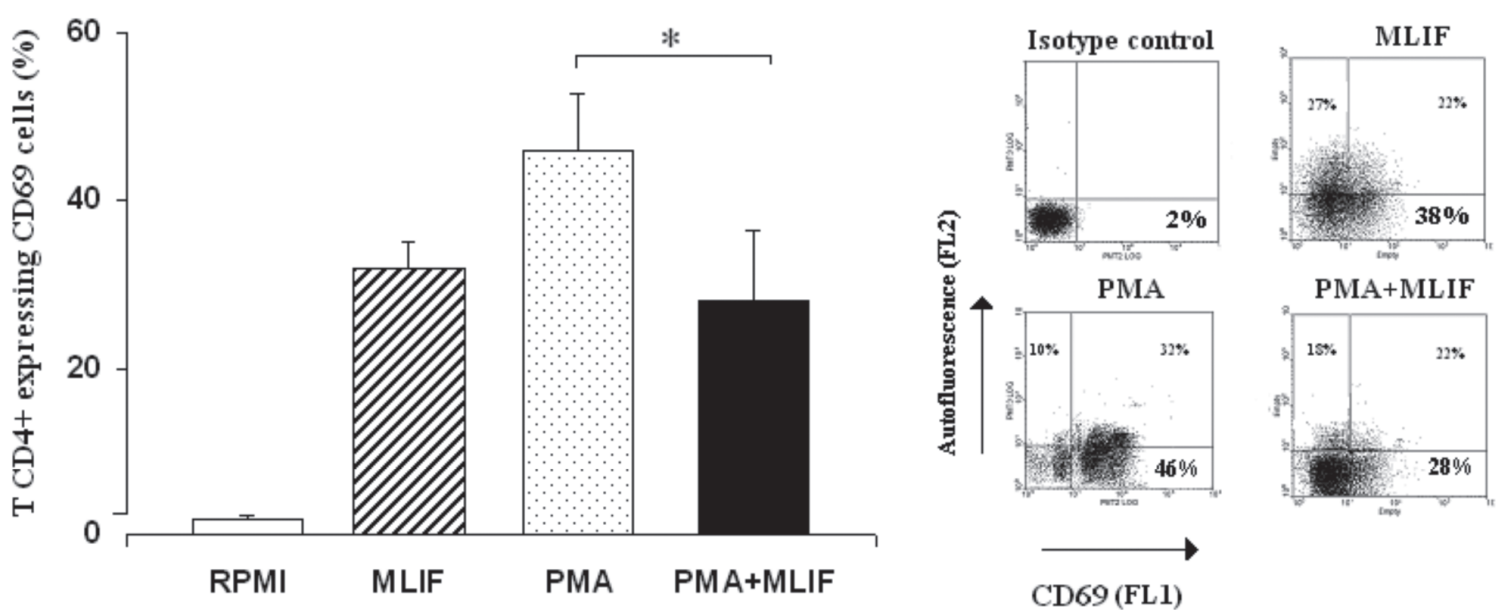

Fig 1: CD69-activation marker expression in T CD4+ cells: $5 \times 10^{5}$ CD4+ T lymphocytes were obtained from human peripheral blood by Ficoll-Hypaque gradient. They were purified with the negative selection technique and incubated for $24 \mathrm{~h}$ with RPMI, MLIF (50 $\mu \mathrm{g} / \mathrm{mL}$ ), PMA (50 ng/ $\mathrm{mL})$, or PMA+MLIF. Cells were stained with FITC anti-CD-69 mAbs (10 mL X $10^{5}$ cells). Quadrant markers were set based on a fluorescent IgG isotype control. Histograms show mean values \pm SEM. The numbers in each quadrant of the dot plots correspond to the percentage of CD69 activation marker expression in T CD4+ cells; bold numbers show the mean of three independent experiments. Asterisk indicates the statistically significant differences between the percentages of CD69- producing cells among the groups when *p $<0.05$ (Mann-Whitney Test). 
$32 \%$, respectively) was significantly different $(\mathrm{p}<0.05)$ when compared to the constitutive expression. With the treatment of PMA+MLIF the production of cytokines was $57 \%, 41 \%, 4 \%, 50 \%$ and $38 \%$, respectively. MLIF inhibited the production of IFN- $\gamma$ induced for PMA $(\mathrm{p}<0.002)$ (figure 3).

Cytokine and chemokine receptor coexpression

The presence and up-regulation of cytokines and chemokines receptors were studied with MLIF (Thl/CCR5 and Th2/ CCR4). Briefly, in control CD4+ T cells, $2 \%$ co-expressed IL-1 $\beta / C C R 5$, IL-2/CCR5, and IFN- $\gamma / \mathrm{CCR} 5$, while $3 \%$ co-expressed IL-4/CCR4, and 1\% co-expressed IL-10/ CCR4. After stimulating CD4+ T cells with MLIF, $15 \%$ cells co-expressed IL- $1 \beta /$ CCR5, 21\% IL-2/CCR5, and 16\% IFN- $\gamma$ / CCR5, while $18 \%$ co-expressed IL-4/CCR4 and $16 \%$ IL-10/CCR4. PMA increased the expression of all of them $(24 \%, 28 \%, 23 \%$, $32 \%$, and $31 \%$, respectively) and the combination PMA+MLIF showed that MLIF inhibited significant IL-1 $\beta / C C R 5$ $(\mathrm{p}<0.05)$ and IFN- $\gamma /$ CCR5 $(\mathrm{p}<0.002)$ induced by PMA (figure 4).

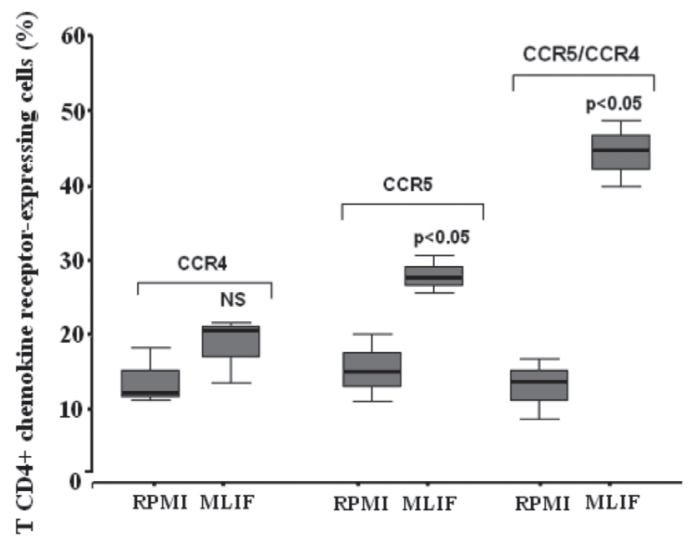

Fig 2: Expression profiles of CCR4, CCR5 and CCR4/CCR5 on isolated CD4+ T cells: $5 \times 10^{5}$ CD4+ T lymphocytes were cultured for $24 \mathrm{~h}$ with RPMI or MLIF (50 mg/mL). Cells were stained with PE or FITC anti- human CCR4, anti human -CCR5, or anti-human CCR4/CCR5 mAbs. Box plots represent range, 25th and 75th percentiles, vertical lines represent the 10th and 90th percentiles of data. Horizontal bars show significant statistical differences among the different groups. NS = no significant difference. Values (p) were calculated using Mann-Whitney Test. Dot plots show the co-expression of CCR4/CCR5 and bold numbers are the mean of three independent experiments.
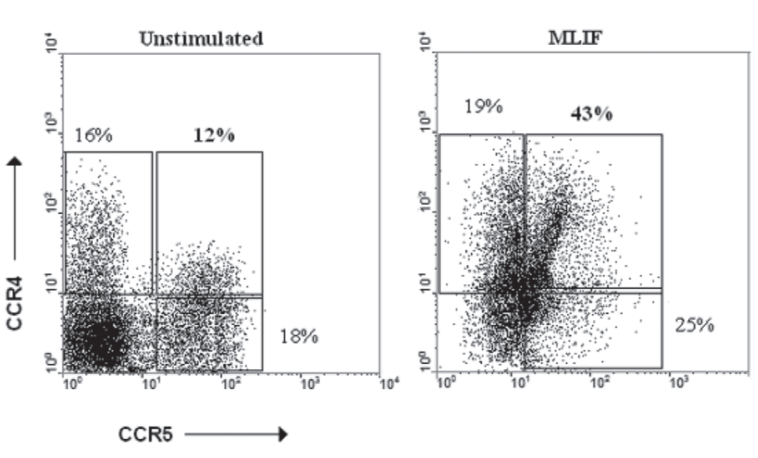

Different diseases (rheumatoid arthritis, HIV infection, liver infection, parasitism etc.) have been associated with the Th1/ Th2 balance but the mechanisms have not been completely clarified (Leng 2008, Power 2000, Katzman 2008, Shields 1999, Kaur 2008). Down-regulation of the immune response is a common parasite strategy.

E. histolytica produces the Monocyte Inhibitory Locomotion Factor (MLIF), a pentapeptide with powerful antiinflammatory, selective properties tested in vitro and in vivo (Kretschmer et al., 1985). MLIF seems to be exclusive of the Entamoeba histolytica and other related amebas (E. invadens, E. moshkovski (Kreschmer et al, 1985)), but is absent in $E$ dispar (Silva et al., 2000), as we corroborated through the gene bank, where we only found the MLIF genetic sequence in the Entamoeba histolytica, and to date not in other parasites.

Infection caused by Entamoeba histolytica induces a transitory cellmediated immunity-suppressed state in early inflammatory stages in the amebic hepatic abscess (AHA), and a complex 

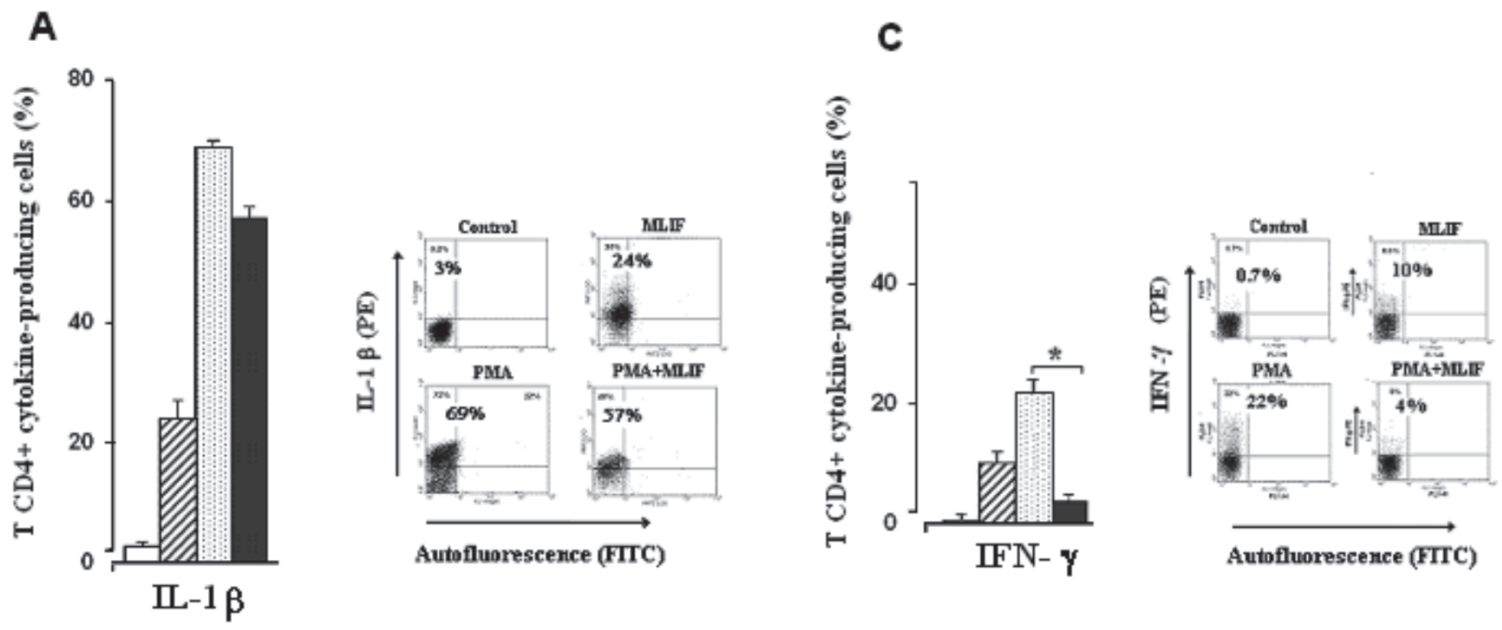

\section{B}
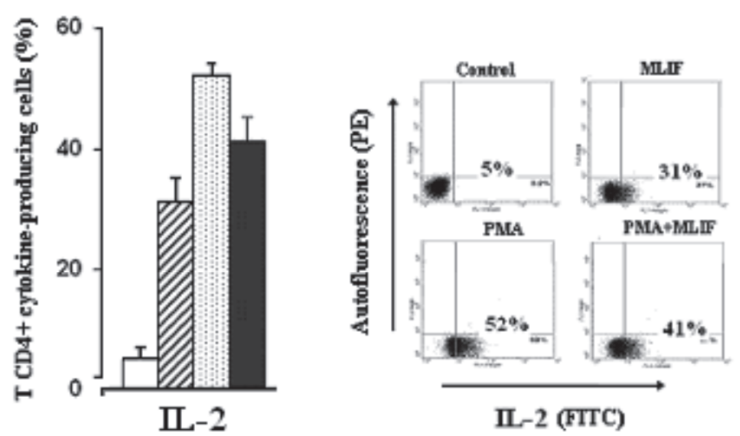

Fig 3: Intracellular cytokine production: $5 \times 10^{5} \mathrm{CD} 4+\mathrm{T}$ lymphocytes were cultured for $24 \mathrm{~h}$ in the presence of RPMI, MLIF, PMA, or PMA+MLIF. Brefeldin A (cellular transport inhibitor (10 $\mu \mathrm{g} / \mathrm{mL}$ ) was added during the last $6 \mathrm{~h}$ of culture. Cells were permeabilized and stained with antihuman cytokine mAbs (IL-1 $\beta$, IL-2, IFN $\gamma$, IL-4, and IL-10) and mouse anti-IgG as isotype control. FACScan dot plots are representative of control and of the cells treated; the numbers in each quadrant indicate the mean of the 6 independent experiments. In A, B, C, D, and E the histograms represent control (white), MLIF (diagonals), PMA (dotted) PMAM+ MLIF (black) and represent mean values \pm SEM. Asterisk shows comparison among groups, ${ }^{*} p<0.05$ (Mann-Whitney Test). Bold numbers (dot plots) represent the mean.

cytokine signaling system is activated due to invasion of the parasite (Eckmann et al., 1993).

The effect of MLIF upon the production of cytokines was previously evaluated in a short study using the ELISA method (Rojas et al., 2006). Consistent with the present research, the previous study showed that MLIF was able to modify the production of Th1/Th2 cytokines in the supernatants of cultures of T CD4+ lymphocytes stimulated with PMA or MLIF. We found that
MLIF+PMA inhibited the IL-1 $\beta$, IL-5, and IL- 6 production without affecting the IL-10 production.

In the present study, we demonstrated that MLIF per se possessed the ability to unspecifically activate T CD4+ cells and induce an increase in pro- and antiinflammatory cytokine production (IL-1 $\beta$, IL-2, IFN- $\gamma$, IL-4, and IL-10). In contrast, in PMA +MLIF-incubated cells, we found that IFN- $\gamma$ and IL- $1 \beta$ production was inhibited; whereas it increased the 

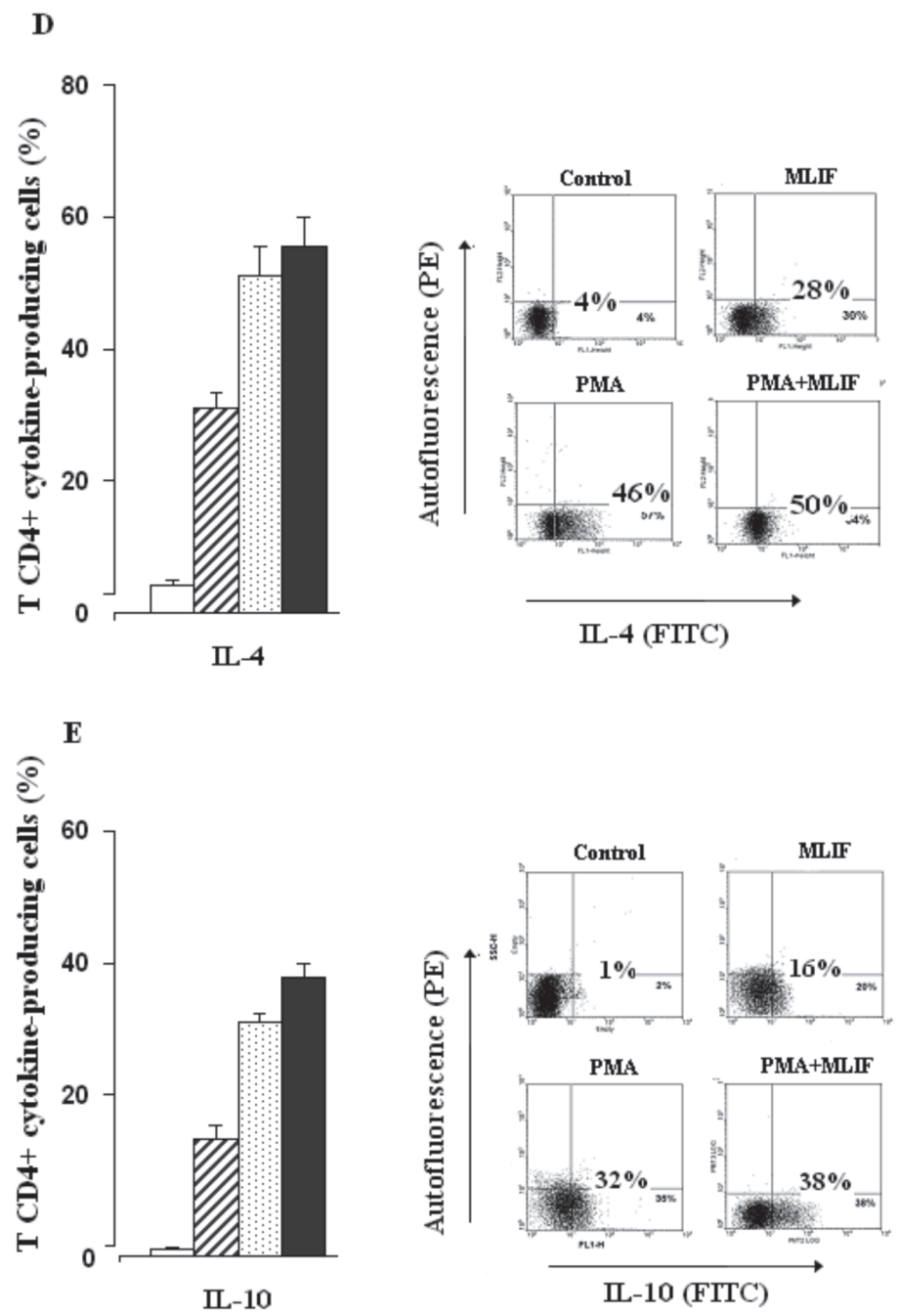

Fig 3: cont.

production of IL-10 (the prototype of an anti-inflammatory cytokine).

It is probable that MILF generates a signaling cascade, which finally activates transcription factors such as nuclear factor kB (NF-kB) (Kretschmer et al., 2004); after its translocation into the nucleus, it binds to sites regulating a large number of cytokine production-implicated genes. In this way, $E$. histolytica may establish, first an acute transitory reaction involving proinflammatory cytokines, followed by an increase and dominant pattern of antiinflammatory signals mainly through the increase in interleukin-10. IL-10 could cause a decrease of the inflammatory reactions observed in the advanced states of invasive amebiasis (Kretschmer et al.,
1985). Additionally, cell activation may modify the expression of chemokines and chemokine receptors, which, in alternate fashion, are essential for leukocyte recruitment during inflammation. Once activated, $\mathrm{T}$ lymphocytes acquire different migratory capacities and are, in fact, key for an efficient immune-response regulation (Mackay, 1993, Katakai et al., 2002). CCR5 is a receptor that regulates normal $\mathrm{T}$-cell activation, and it was expressed in the tested Th1 cytokines. Nonetheless, when these were exposed to MLIF (PMA+MLIF) they were inhibited and the decrease was significant, at least for IFN- $\gamma$ and IL- $1 \beta$. IFN- $\gamma$ exerted a strong influence on Th1/ Th2 polarization and also affected chemokine receptor expression; MLIF per 
A
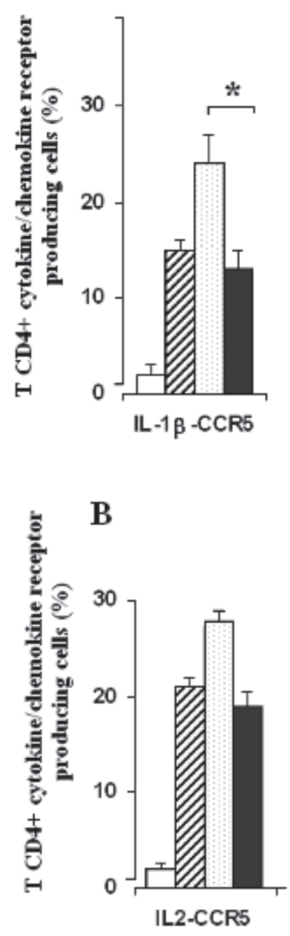
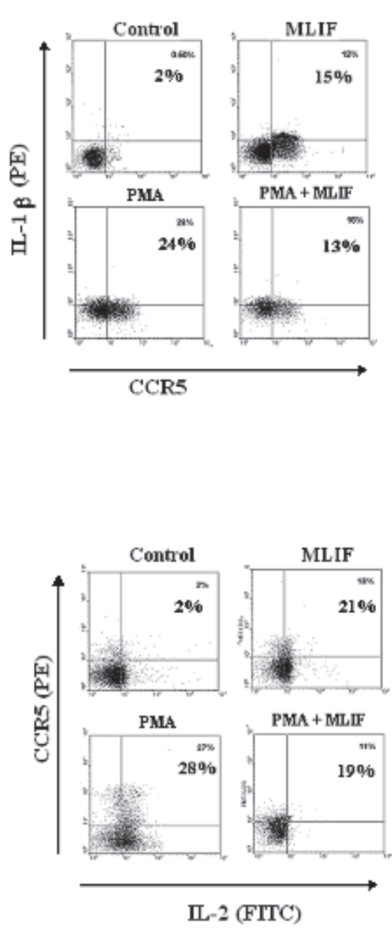

C
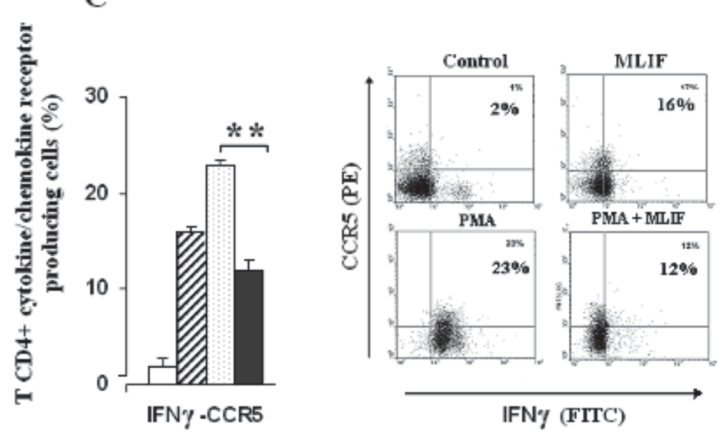

Fig 4: Cytokine, and chemokine receptor co-expression: Cells were cultured with RPMI, MLIF, PMA, and PMA+MLIF for $24 \mathrm{~h}$ at the previously mentioned concentrations. Brefeldin A was added during the last $6 \mathrm{~h}$ of culture. Cells were first stained to detect the surface cell molecules with antihuman CCR5 or anti-CCR $4 \mathrm{mAbs}$, then they were permeabilized and stained with anti-cytokine mAbs (IL-1 $\beta / C C R 5$, IL-2/CCR5, IFN $\gamma / C C R 5$, IL-4/CCR4, and IL-10/CCR4) and were analyzed on a flow cytometer. A,B,C,D, and E. FACScan dot plots are representative staining of the control and the treated cells, bold numbers represent the mean of the 6 additional experiments. The histograms represent control (white), MLIF (diagonals) PMA (dotted) PMAM+ MLIF (black) and represent mean values \pm SEM. Asterisks show the comparison among of groups, ${ }^{*} \mathrm{p}<0.05,{ }^{*} \mathrm{p}<0.002$ (MannWhitney Test).

$s e$ induced an increase in the CCR5 and CCR4 receptors, only significant in the first. CCR5 increase was stronger in CCR4+ than in CCR4- cells (31\% vs. 7\%). This does not allow considering the increase as a pro-Th1 response. We demonstrated that these molecules, which are key factors in immune regulation, are affected by MLIF. Th2 exhibited high CCR4 expression levels in response to MLIF and when co-expressed, this expression increased to an even higher level, demonstrating that MLIF possessed an additive effect on these markers, at $24 \mathrm{~h}$ in these experimental conditions.

The precise mechanisms that MLIF uses to cause these biological effects are unknown; however, it is known that MLIF interacts with human leukocytes by means of a mannose-containing receptor (Kretschmer et al., 1991), and that it causes an increase in the number of pericentriolar microtubules, as well as in cytoplasmic AMPc concentration, without concomitant GMPc diminution (Rico et al., 1995). MILF inhibits the expression induced in inflammatory proteins such as MIP- $1 \alpha$ and MIP-1 $\beta$ in U-937 cells, which are NF-kB pathway-regulated proteins, as described in literature (Utreras-Barillas et al., 2003). The p65-p50 heterodimer comprises the most abundant form of NF-kB in a PMAinduced system. Temporary studies showed that MLIF induces p50 translocation; this 
Fig 4: Cont.

D
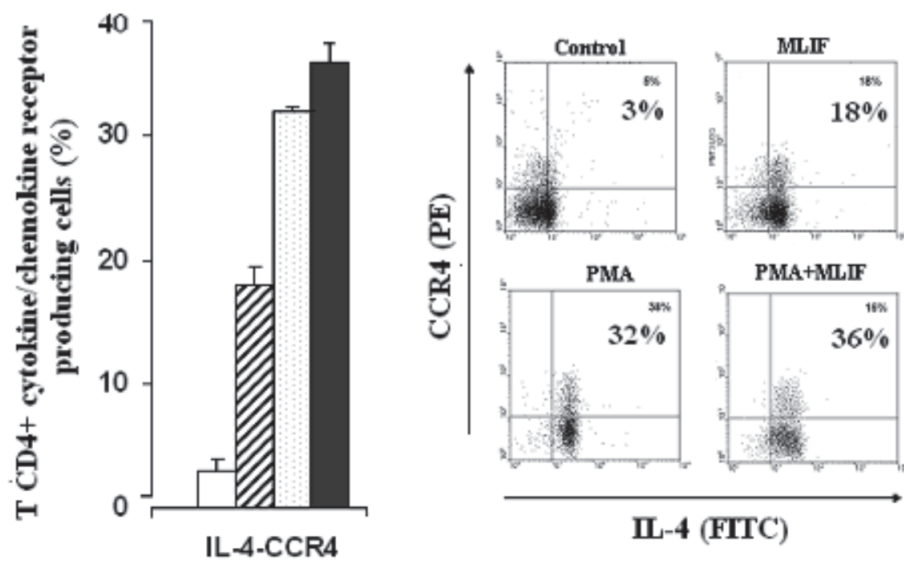

$\mathbf{E}$
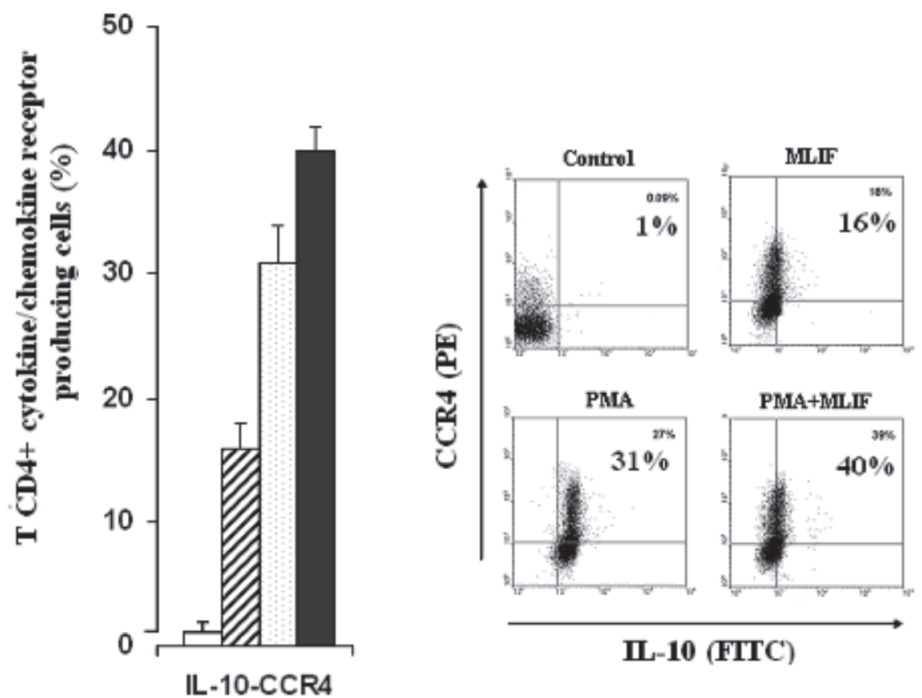

can also be explained by the fact that MLIF induces AMPc synthesis and protein kinase A phosphorylation in NF-kB, IkB, followed by NF-kB translocation (Kretschmer $\mathrm{R}$ et al., 2004).

A still unanswered question is whether MLIF is a real inhibitor or a competitive antagonist - or both - depending on cells and conditions (e.g. values of MLIF alone are higher than in resting RPMI conditions, but MLIF+PMA values are lower than those for active PMA cells). This is the tendency for pro-Th1 factors. On the contrary, MLIF+PMA rendered the highest values for Th2 representatives as IL-10. Despite details in the molecular and cellular microenvironment, the overall in vivo effect

was inhibiting. MLIF effects have proven to be somehow sui-generis in many studies, as for example: MLIF inhibits locomotion and phagocytosis in mononuclear cells, but only phagocytosis in neutrophil PMN, and not in eosinophils; it inhibits cytoskeleton function over-polymerization the microtubule, opposite to what happens with colchicines. In spite the amount of changes in the cells by MLIF, there is an excellent cellular viability, therefore it apparently does not lead to apoptosis or necrosis.

Given the level of activity of the studied cytokines, we observed that MLIF acted the promotion of the cell populations that express IL-2/IL-10 or IFN- $\gamma /$ IL-10 and CCR4/CCR5. This type of behavior has been 
reported before and it is associated with proand anti-inflammatory functions (Katsikis et al., 1995). In previous works, it was observed that MLIF inhibited the expression induced in the CC, MIP- $1 \alpha$, MIP- $1 \beta$, and I309 chemokines, the CCR1 receptor (UtreraBarrillas et al., 2003), and the IL-1 $\beta$, IL-5, and IL-6 cytokines (Rojas-Dotor et al., 2006). This behavior can be related with the atypical inflammation observed in invasive amebiasis, in which there is a decrease in chemotaxis and/or disequilibrium in cytokine production. This is supported by observations in vivo in which MLIF notably decreased cellular infiltration and inflammatory cytokine expression.

The effect of MLIF observed in this study could be explained by Th1 inhibition, as was observed with IL- $1 \beta / \mathrm{CCR} 5$, IFN- $\gamma$ / CCR5 and an increase of Th2, as was found in IL10/CCR4 expression, resulting in the predominantly anti-inflammatory $\mathrm{Th} 1<\mathrm{Th} 2$ pattern.

\section{ACKNOWLEDGEMENTS}

This research was supported by the Consejo Nacional de Ciencia y Tecnología (CONACYT), México (No. 38104-M). The authors wish to thank Dr. Cecilia Ximénez, UNAM, Maggie Brunner and American Journal Experts for the critical review in English of the manuscript. The authors are grateful to laboratory technician José de la Luz Romero Preciado from the Blood Bank in Centro Médico Nacional Siglo-XXIIMSS, México, D. F. México.

\section{REFERENCES}

ANDREW DP, RUFFING N, KIM CH, MIAO W, HEATH H, LI Y, MURPHY K, CAMPBELL JJ, BUTCHER EC, WU L (2001) C-C chemokine receptor 4 expression defines a major subset of circulating nonintestinal memory $\mathrm{T}$ cells of both Th1 and Th2 potential. J Immunol 166: 103-111

BÖYUM A (1968) Isolation of mononuclear cells and granulocytes from human blood. Scand J Clin Lab Invest 97: 77-89

CAMBIAGGI C, SCUPOLI MT, CESTARI T, GEROSA F, CARRA G, TRIDENTE G, ACOLLA RS. (1992) Constitutive expression of CD69 in interspecies Tcells hybrids and locus assignment to human chromosome 12. Immunogenetics 36: 117-20
CAMPBELL JD, HAYGLASS KT (2000) T cell chemokine receptor expression in human Th1 and Th2 associated diseases. Arch Immunol Ther Exp 48: 451-456

CHADEE K, MEEROVITCH E (1984) The pathogenesis of experimentally induced amebic liver abscess in the gerbil (Meriones unguiculatus). Am J Pathol 117: 7180

DAMBROSIO D, IELLEM A, BONNECCHI R, MAZZEO D, SOZZANI S, MANTOVANI A, SINIGAGLIA F (1998) Selective up-regulation of chemokine receptors CCR4 and CCR 8 upon activation of polarized human type 2 Th cells. J Immunol 161: 5111-5115

ECKMANN L, JUNG HC, SCHÜRER-MALY C, PANJA A, MORZYCKA-WROBLEWSKA E, KAGNOFF M (1993) Differential cytokine expression by human intestinal epithelial cells lines: regulated expression of interleukin-8. Gastroenterology 105: 1689-1697

FRESHNEY R (1987) Scaling-up of animal cell cultures. In: Rickwood D, Hames BD(eds) Culture of Animal Cells: A Manual of Basic Technique. 2nd ed. New York: Irls press. pp 47-92

GIMÉNEZ-SCHERER JA, ARENAS E, DÍAZ L, RICO G, FERNÁNDEZ J KRETSCKMER R (2000) Effect of the monocyte locomotion inhibitory factor (MLIF) produced by Entamoeba histolytica on the expression of cell adhesion molecules (CAMs) in the skin of guinea pigs. Arch Med Res 1: 92-93

GIMÉNEZ-SCHERER JA, CÁRDENAS G, LÓPEZOSUNA M, VELÁZQUEZ JR, RICO G, ISIBASI A, MALDONADO MC, MORALES ME, FERNANDEZDÍEZ J, KRETSCHMER RR (2004) Immunization with a tetramer derivative of an anti-inflammatory pentapeptide produced by Entamoeba histolytica protects gerbils (Meriones unguiculatus) against experimental amoebic abscess of the liver. Parasite Immunol 26: 343-349

GIMÉNEZ-SCHERER JA, PACHECO-CANO MG, CRUZ DE LAVÍN E, HERNÁNDEZ-JÁUREGUI P, MERCHANT MT, KRETSCHMER R (1987) Ultrastructural changes associated with the inhibition of monocyte chemotaxis caused by products of axenically grown Entamoeba histolytica. Lab Invest 57: 45-51

GIMÉNEZ-SCHERER JA, RICO-ROSILLO G, FERNÁNDEZ-DÍEZ J, KRETSCHMER R (1997) Inhibition of contact cutaneous delayed hypersensitivity reactions to DNBC in guinea pigs by the monocyte locomotion inhibitory factor (MLIF) produced by axenically grown Entamoeba histolytica. Arch Med Res 28: 237-238

KATAKAI T, HARA T, SUGAI M, GONDA H, NAMBU Y, MATSUDA E, AGATA Y, SHIMIZU A (2002) Chemokine-independent preference for T-helper-1 cells in transendothelial migration. J Biol Chem 277: 5094850958

KATSIKIS PD, COHEN SB, LONDEI M, FELDMANN M (1995) Are CD4+ Th1 cells pro-inflammatory or antiinflammatory? The ratio of IL-10 to IFN-g or IL-2 determines their function. Int Immunol 7: 1287-1294

KATZMAN SD, FOWELL DJ (2008) Pathogen-imposed skewing of mouse chemokine and cytokine expression at the infected tissue site. J Clin Invest 118:801-811

KAUR S, KAUR T. GARG N, ATHOKPAM V (2008) Effect of dose and route of inoculation on the generation of CD4+ Th1/Th2 type of immune response in murine visceral leishmaniasis. Parasitol Res 103:1413-9

KRETSCHMER R, COLLADO ML, PACHECO M, SALINAS M, LÓPEZ-OSUNA, LECUONA M, CASTRO E, ARELLANO J (1985) Inhibition of human 
monocyte locomotion by products of axenically grown E. histolytica. Parasite Immunol 7: 527-543

KRETSCHMER R, RICO G, GIMÉNEZ J (2001). A novel anti-inflammatory oligopeptide produced Entamoeba histolytica. Mol Biochem Parasitol 112: 201-209

KRETSCHMER R, VELÁZQUEZ J, UTRERAS BARILLAS D, ZENTELLA A (2004) The amibic antinflammatory monocyte locomotion MLIF inhibits the NF-kB nuclear translocation in human monocytes. FASEB J: 18-A1147

KRETSCHMER RR, CASTRO EM, PACHECO G, RICO G, DÍAZ-GUERRA O, ARELLANO J (1991) The role of mannose in the receptor of the monocyte locomotion inhibitory factor produced by Entamoeba histolytica. Parasitol Res 77: 374-378

LENG J, YAO H, SHEN J, WANG K, ZHUO G, WANG Z (2008) Co-expression of IL-18 binding protein and IL4 regulates Th1/Th2 cytokine response in murine collagen-induced arthritis. Acta Biochim Biophys Sin 40:116-24

LOETSCHER P, UGOCCIONI M, BORDOLI L, BAGGIOLINI M, MOSER B, CHIZZOLINI C, DAYER JM (1998) CCR5 is characteristic of Th1 lymphocytes Nature 391: 344-345

MACKAY CR (1993) Homing of naive, memory and effector lymphocytes. Curr Opin mmunol 5: 423-427

MILTENYI S, MULLER W, WEICHEL W, AND RADBRUCH A (1990) Cytometry 11: 31-238

MOSMANN T, FONG T (1989) Specific assays for cytokine production by $\mathrm{T}$ cells. J Immunol Meth 116: 151-158

POWER CA (2000) Factors that influence T helper cell response to infection. Curr Opin Infect Dis 13:209-213

REDDY M, EIRIKIS E, DAVIS C, DAVIS HM, PRABHAKAR U (2004) Comparative analysis of lymphocyte activation marker expression and cytokine secretion profile in stimulated human peripheral blood mononuclear cell cultures: an in vitro model to monitor cellular immune function. J Immunol Methods 293:127-42

RICO G, DÍAZ-GUERRA O, GIMÉNEZ-SCHERER JA, KRETSCHMER R (1992) Effect of the monocyte locomotion inhibitory factor (MLIF) produced by Entamoeba histolytica upon the respiratory burst of human leucocytes. Arch Med Res 23: 157-159

RICO G, DÍAZ-GUERRA O, KRETSCHMER R (1995) Cyclic nucleotide changes induced in human leukocytes by a product of axenically grown Entamoeba histolytica that inhibits human monocyte locomotion. Parasitol Res 81: 158-162

ROJAS-DOTOR S, RICO G, PÉREZ J, VELÁZQUEZ J, KRETSCMER R (2006) Cytokine expression in CD4+ cells exposed to the monocyte locomotion inhibitory factor produced by Entamoeba histolytica. Parasitol Res 98: 493-495

SALLUSTO F, MACKAY CR, LANZAVECCHIA A (1998) Flexible programs of chemokine receptor expression on human polarized $\mathrm{T}$ helper 1 and 2 lymphocytes. J Exp Med 187: 875-883

SEBASTIANI S, ALLAVENA P, ALBANESI C, NASORRI F, BIANCHI G, TRAIDL C. SOZZANI S, GIROLOMONI G, CAVANI A (2001) Chemokine receptor expression and function in $\mathrm{CD} 4+\mathrm{T}$ lymphocytes with regulatory activity. J Immunol 15 : 996-1002

SHIELDS PL, MORLAND CM, SALMON M, QIN S, HUBSCHER SG, ADAMS DH (1999) Chemokine and chemokine receptor interaction provide a mechanism for selective $\mathrm{T}$ cell recruitment to specific liver compartments within hepatitis $\mathrm{C}$ infected liver. J Immunol 163:6236-43

SILVA R, RICO G, ESPINOSA-CANTELLANO M, GIMÉNEZ JA, KRETSCHMER R (2000) Does Entamoeba dispar produce monocyte locomotion inhibitory factor (MLIF) like Entamoeba histolytica? . Arch Med Res 31:S94-5

SORIANO-CORREA C, SÁNCHEZ-RUIZ JF, RICOROSILLO G, GIMÉNEZ-SCHERER JA, VELÁZQUEZ JR, KRETSCHMER R (2006) Electronic structure and physicochemical properties of the anti-inflammatory pentapeptide produced by Entamoeba histolytica: Theoretical study. J Molecular Structures: THEOCHEM 769: 91-95

TALVANI A, ROCHA MO, RIBEIRO AL, CORREAOLIVEIRA R, TEIXEIRA MM (2004) Chemokine receptor expression on the surface of peripheral blood mononuclear cells in Chagas disease. J Infect Dis; 189: 214-20

UTRERA-BARRILLAS D, VELÁZQUEZ JR, ENCISO A, CRUZ SM, RICO G, CURIEL-QUEZADA E, TERAN LM, KRETSCHMER R (2003) An anti-inflammatory oligopeptide produced by Entamoeba histolytica downregulates the expression of pro-inflammatory chemokines. Parasite Immunol 25: 475-482 
